\title{
COMMENTARY
}

\section{A Social Psychology of Human Rights Rooted in Asymmetric Intergroup Relations}

\author{
Christian Staerklé, Alain Clémence, and Dario Spini \\ University of Lausanne
}

\begin{abstract}
Reflecting the increasing importance of human rights (HR) in legal theory and socialscientific research, psychologists and social scientists have developed an increased interest in the topic. Although the first systematic social psychological research that explicitly deals with HR dates back to the 1990s, particularly that of Willem Doise and his colleagues (Doise, 2002), researchers have recently rediscovered both the political and the scientific importance of a social psychological analysis of HR. The present special issue is a timely and powerful statement of the relevance of a psychological analysis of HR and their role in everyday thinking regarding social inequality, intergroup injustice, and widespread suffering stemming from armed conflict, intergroup violence, and rightsviolating authorities. It thereby also reflects a
\end{abstract}

Christian Staerklé holds a PhD and is an associate professor of social psychology at the Institute of Psychology at the University of Lausanne in Switzerland and docent of social psychology at the University of Helsinki in Finland. His research interests cover social representations, intergroup attitudes, and political legitimacy.

ALAIN CLÉMENCE holds a PhD and is a professor of social psychology at the Institute of Psychology at the University of Lausanne in Switzerland. His research area includes social identity and social representations, violence and human rights, and transformation of expert information in the daily life.

DARIO SPINI holds a $\mathrm{PhD}$ and is a professor at the Institute for Social Sciences, University of Lausanne. He is the director of the Swiss National Centre for Competence in Research LIVES: "Overcoming vulnerabilities: Life course perspectives." His research interests include identity, health and well-being in old age, intergroup conflicts, collective victimization, human rights, and advanced methodological applications.

CORRESPONDENCE CONCERNING THIS ARTICLE should be addressed to Christian Staerklé or Alain Clémence, Faculty of SSP, UNILaps, Geopolis, University of Lausanne, 1015 Lausanne, Switzerland. E-mail: christian.staerkle@unil.ch or alain.clemence@unil.ch growing awareness of global issues among psychologists.

The articles enclosed in the special issue of Peace and Conflict: Journal of Peace Psychology could appear, at first glance, as a set of disparate contributions to the social psychology of human rights. But after reading through all the contribution, a rich and coherent puzzle emerges. The diverse theoretical and methodological approaches of the four empirical studies offer a stimulating extension of the general review opening the issue, and the last contribution develops a relevant theoretical framework to integrate and discuss the research. In sum, the issue shows how (social) psychology powerfully sheds light on the enormous problems associated with the respect for and the violations of elementary rights of people. Basic research in social psychology tells us that we all are potential executioners when supported by certainties concerning the moral superiority of the self and of our group. But, as underlined by Doise (2002), this pessimistic point of view does not subsume contrasting research showing how we can contribute to protecting persons from mistreatments, discrimination, or oppression. The set of articles in this issue illustrates both the optimistic and pessimistic views on the respect for human rights. We have organized our commentary around three core points that are discussed to various degrees in the different articles, and are central in accounting for the factors that promote and limit respect for human rights.

\section{People Support Abstract HR Principles, but Exclude Bad Individuals From These Principles}

The analysis of HR definitions by lay people is at the same time an empirical necessity and an empirical problem. Formally, HR are rights in- 
herent to all human beings independently of their membership in national, ethnic, religious, gender, or age categories. They are codified and guaranteed by law, in the form of declarations, in particular the Universal Declaration of $\mathrm{Hu}-$ man Rights (UDHR) of 1948, treaties, conventions, resolutions, and other sources of international law. Yet, when ordinary people think of HR, they may not always apply the fundamental HR principles of universality and indivisibility. Instead, they reconstruct HR to bring them into line with everyday constraints and purposes. The articles in this special issue deal with these transformations of HR into everyday thinking, by showing the various ways through which HR are translated and adapted by lay people.

In his review of empirical research, Sam McFarland (2015) raises this issue as relating to the measurement of agreement with HR and discusses how their level of abstraction determines agreement with HR. Yet, it is not only a question of a higher or lower level of abstraction in the definition of HR, but also a question of meaning that is embedded in specific cultural or linguistic contexts, as demonstrated by Kathleen Malley-Morrison, Ross Caputi, Ellen Gutowski, Tristyn Campbell, and their colleagues (2015). Each article in this issue discusses the problem of the meaning of HR for ordinary citizens. The articles also address the vertical gap between abstract definitions and specific judgments, as well as the horizontal gap between judgments on different national contexts or social groups. This is why Doise and his colleagues have tackled HR as a social representation to analyze the various translations of the formal definition of the UDHR into ordinary thinking, showing that the UDHR acts as the most relevant reference for lay people around the world. For present purposes, social representations can be defined as a form of everyday knowledge that lay people rely upon to judge and make up their minds on important social and political issues (see Clémence, 2001; Elcheroth, Doise, \& Reicher, 2011; Moscovici, 1961/2008; Staerklé, 2009). One of the cornerstones of the theory is that we use different modes of reasoning depending on the constraints imposed by different social contexts. In everyday life, we follow a mode of reasoning based on the actual thought content and the necessity of successful communication with others, while in a specific context such as that of a working laboratory we have to follow logical rules and expert thought procedures (LorenziCioldi \& Clémence, 2001).

It is in the context of such lay thinking described by social representations theory that one may understand why individuals restrict the universality of HR by accepting HR violations under certain circumstances and excluding specific groups from protection against bad treatment. Indeed, as underlined by McFarland (2015), the universality of a positive attitude toward HR appears to be restricted to the formal and abstract definition of HR. When people evaluate the implementation of HR across different contexts, they become divided and support restrictions (see also Spini \& Doise, 1998; Staerklé \& Clémence, 2004). This is clearly documented by the studies of Dominic Abrams, Diane Houston, Julie Van de Vyer, and Milica Vasilevic (2015), showing that a significant group of adults (between 15\% and 30\%) in the United Kingdom attribute more rights to paternalized groups than to nonpaternalized groups, even if they claim to endorse equality principles for all groups.

The restriction of HR appears particularly dramatic when it concerns one of the most absolute or inalienable rights (Delmas-Marty, 1989), namely the protection against torture and inhumane or degrading treatment (Article 5 of the UDHR). McFarland (2015) reports the results of a large survey conducted in 2008 in 19 countries by the Program on International Policy Attitudes on the views on torture (Kull et al., 2008). However, McFarland's (2015) conclusion about "rather stable between-country differences" appears questionable. First of all, it must be noted that in 2008 the prohibition of torture was supported by less than half of the participants in seven countries (Russia, Iran, Turkey, Nigeria, South Korea, Thailand, and India) and by more than three quarters in only three countries (Spain, France, and Great Britain). The evolution between 2006 and 2008 for the 15 countries where the same survey was conducted repeatedly shows a clear increase in support for allowing the state to use "some degree of torture if it may gain information that saves innocent lives" in India, Turkey, and South Korea, but also in Nigeria and the U.S. and, in contrast, an increase in the support of the absolute prohibition of torture in Mexico, Spain, China, Indonesia, Great Britain, and (to a 
lesser extent) Russia. These results illustrate a dramatic volatility in the public support for one of the core human rights when it is defined in a specific context. They also show strong international differences that cannot be fully accounted for by the proximity of terrorist attacks.

The article by Malley-Morrison and colleagues (2015) offers another way to understand judgments on this classic torture dilemma. The analysis of the brief narratives provided by the respondents reveals that, in addition to the national context of the participants, both moral reasoning in terms of moral disengagement versus moral engagement, and membership in an activist group, shape HR judgments. As a result, the definition of rights is associated with the definition of those who deserve the rights ("good" citizens) and those who should not benefit from them ("bad" citizens and terrorists!).

\section{Dominant Claims for Duties and Subordinate Claims for Rights}

The articles further show how identity and intergroup processes shape people's thinking about and behavior toward HR and thereby also illustrate the extent to which everyday thinking is embedded in relations within and between groups. Following other research (e.g., Cohrs, Maes, Moschner, \& Kielmann, 2007; Stellmacher, Sommer, \& Brähler, 2005) and Duckitt's (2001) dual process model, McFarland (2015) highlights the strong negative impact of Social Dominance Orientation (SDO) and Right Wing Authoritarianism (RWA) on people's support of different aspects of HR. With respect to SDO, these findings suggest that the support of intergroup inequality specifically decreases support for the rights of minorities and other marginalized groups, that is, rights that are less consensual and that are contested by significant segments of the population. The refusal to grant rights to minorities thereby becomes a strategy to legitimize intergroup inequality. The negative effect of RWA on HR support, in turn, indicates that conventionalism and punitiveness increase the tendency to exclude non-normative individuals - that is, those who violate common group norms-from rights protection. These two constructs appear to explain most of the variance of individual differences in attitudes toward HR, providing a first indication that group-level beliefs are key to understanding HR support and rejection.

But other aspects of social identity and intergroup relations appear in the articles too. McFarland (2015) introduces this point by showing the importance of the level of self-categorization in the positioning toward HR principles. The more people endorse a higher level of selfcategorization, up to the human level (Turner, Hogg, Oakes, Reicher, \& Wetherell, 1987), the more they favor the universality of HR. When social identity is defined at a lower level, the context of intergroup relations introduces some restrictions in attitudes toward and the application of HR principles. Justin Hackett, Allen Omoto, and Miriam Matthew (2015) propose an elegant model where the psychological sense of global community (PSGC) shapes attitudes toward HR concern and behavior and connects them to self-transcendence values. PSGC may appear as a form of social identity if we consider the items used by authors, who discuss this point in their conclusion. Indeed, participants define themselves as belonging to humanity and as an interchangeable member of a unique human group.

However, the positive effect of superordinate identities is not the only logic at work in the determination of HR support. HR are by definition experienced and implemented in asymmetrical intergroup contexts, between dominant and subordinate groups, or between victim and perpetrator groups (e.g., between enemy groups in an armed conflict, or between the citizenry and law enforcement authorities). As a result, both individuals' own position in asymmetrical intergroup relations and their subjective positioning toward minorities and majorities (in terms of positive or negative attitudes toward minorities and minority norms) play an important role in shaping people's thinking about HR. Put differently, HR thinking necessarily involves representations of asymmetric intergroup antagonisms.

A first indication of the importance of intergroup asymmetries comes from Hackett and colleagues' (2015) finding that the superordinate and supposedly all-inclusive identification with a human category does not actually include all humans to the same degree. The results of Study 2 show that the HR causes that are less endorsed by participants (union movements, immigration, and homosexual issues) correlated 
less with PSGC and self-transcendence values. Participants seem not only less involved in such causes, but they also seem to differentiate good and bad causes in HR much like they differentiate good and bad citizens based on their group membership (Staerklé, 2009). This last intergroup distinction forms the core argument of the article by Abrams and colleagues (2015). Based on a large and representative British sample, they confirm the existence of a deep gap between the endorsement of abstract equality values and concrete support for different minority groups. Using the stereotype content model (Fiske, Cuddy, Glick, \& Xu, 2002) to differentiate "good" and "bad" minority groups, Abrams and colleagues (2015) found that judgments were much more favorable for "paternalized" (i.e., deserving) minorities than for "nonpaternalized" (i.e., undeserving) minorities. They further suggest that the motivation to control prejudice decreases the gap and increases consistency of HR judgments across social groups. The authors thus articulate the discrimination in HR judgments at two levels: (a) an intergroup level (equality hypocrisy) based on the minority status of the groups; and (b) an individual level (equality inconsistency) based on the motivation to control prejudice (Plant \& Devine, 1998). Interestingly, the classification of the target groups largely overlaps with the differences observed in the study by Hackett and colleagues (2015).

The distinction introduces a meaningful dimension to qualify how social identity intervenes in how restrictively $\mathrm{HR}$ are attributed. As Abrams et al. (2015) say, a benevolent or paternalistic view often qualifies relations with the good minorities, those who "instigate feelings of compassion," at least when they do not too loudly claim their rights (women, not feminists, are seen as warm minorities!), whereas a hostile view defines relations with the bad minorities, those who are perceived as threatening the norms of the majority and the dominant group. One can further note that the hostility to bad minorities is often a strategic or political rhetoric used by dominant groups to protect their own rights and privileges. For instance, protecting women's rights against alleged Muslim sexism may be understood as a way to raise awareness of the alleged threat represented by norm plurality. Such a claim then becomes a way both to reaffirm the superiority of the norms of the dominant groups and to legitimize the restriction of minority rights, for example by drawing media attention to how some Muslim women dress.

Moreover, the nonpaternalized minorities are more inclined than the majority and the paternalized minorities to support the equality value, and appear more externally motivated to control prejudice. This result should be highlighted, because it suggests that the motivation to control prejudice is anchored at least partially in group norms. Women and Christians appear to have internalized to a greater degree a nondiscriminating norm than homosexuals, while the rejected minorities seem to conform even more than the majority to the external control of the norm. In this sense, one could regret that Abrams and colleagues (2015) have treated group membership of their participants only as covariates. One might indeed expect some moderation by this group membership when evaluating ingroup rights or when the ingroup is part of the equality comparison.

The articles by Malley-Morrison and colleagues (2015) and by Grabe and Dutt (2015) show that active participation in a movement increases adherence to different facets of HR, particularly behaviorally. This social movement approach was chosen in the two contributions reporting data from people living in Southern countries, but also from authors who actively support HR. The results reinforce a social identity perspective to HR commitment as a representation of human relations and as a motivation for political participation (Elcheroth, Doise, \& Reicher, 2011). The narrative analysis of the discourses of 13 leaders of a feminist movement in Nicaragua reports a vivid and impressive dynamic of the progressive development of HR during the construction of social identity. The process emerges from an awareness of oppression through the experience of a specific unfair event, continues in the participation in the revolutionary movement by belonging to the Frente Sandinista de Liberación Nacional, and finally grows into the construction of a specific women's movement for claiming rights and protecting subordinate (female) minorities against the dominant (male) majority. The dynamic favoring a strong commitment to HR is not based on self-categorization at a higherorder human level, as seen elsewhere, but is supported by a form of subcategorization at a 
lower level to endorse the point of view of a stigmatized minority. Because members of subordinate groups have to find ways to transform a threatening identity, they must consider their own group as human to claim rights, in particular when the boundary to the dominant group is impermeable (Tajfel \& Turner, 1979). In this case, HR intervene as a means to build a positive self and a positive social identity. They also imply recognition of the stigma and involvement in the group to face the stigma (Ethier \& Deaux, 1994; Ellemers, Spears, \& Doosje, 2002).

These seemingly incompatible findings concerning the positive impact of both superordinate and subordinate levels of categorization on HR support and commitment are intriguing. It could be, though, that the specific impact of these levels of identification depends on the insertion of individuals in asymmetric intergroup relations. The dominant majority in Western countries embodies the dominant HR norms. If the support for HR on behalf of dominant Westerners rests on identification at the human level, it could be that this rather abstract sense of global community reflects the idea that their own, predominantly White category legitimately represents the interests of humanity in general (Reese, Berthold, \& Steffens, 2012). Consequently, their own Western norms become the standard through which events occurring mainly outside the Western sphere are judged. For subordinate groups, in turn, commitment to HR requires identification with their group to be able to claim equality of rights. Otherwise, subordinate groups would need to accept the dominant idea that they have to respect the duties defined by the dominant group before being able to claim rights (cf. the debate about right and duties in the excellent book edited by Finkel \& Moghaddam, 2005).

This also suggests that minority members, instead of identifying with other groups, need to engage in a competitive intergroup relation with the majority to denounce HR violations often committed by majority groups and institutions, claim their rights, and ultimately adopt a strategy for achieving social change. As a result, it may well be that minorities use HR in a much more proximal and concrete sense than majorities who refer to HR in their general and abstract form, and for whom HR are first of all an outgroup problem (Moghaddam \& Vuksanovic, 1990). This would mean that fundamentally different processes are at work when minorities or majorities refer to HR in their judgments of social reality. As exemplified by the HR rhetoric employed by the women's movement studied by Grabe and Dutt (2015), minorities use HR to work toward social change, whereas for majorities HR are more likely a tool to redirect attention from ingroup problems to outgroup problems, thereby contributing to the justification of existing social and political arrangements within their groups.

An analysis of this self-serving and strategic use of HR in Western political discourse is largely absent in the special issue. Indeed, there is evidence that HR may at times be used for ethnocentric rather than humanitarian purposes, such as when HR are used to legitimize interventions based on strategic goals of Western countries. Chandler (2002), for example, denounces the hypocrisy of a Western human rights-based foreign policy allegedly grounded in humanitarian motives and the defense of universal values. In social psychology, evidence for an ethnocentric view of HR comes from research on social representations of democracy showing that Western respondents expect non-Western and nondemocratic countries to be inhabited by disorderly and quarreling inhabitants, unable to stand up against a crushing and rights-violating government. Indirectly, then, HR violations are blamed on the people themselves, because they are unable to prevent them from happening. Western inhabitants, on the other hand, are seen not only as orderly and peaceful, but also as free and independent citizens able to resist any attempts by their democratic governments to violate their rights (Staerklé, Clémence, \& Doise, 1998; Staerklé, 2005). Overall, these findings suggest that Westerners employ naïve theories about democratic and nondemocratic functioning, based on a normative and idealized vision of democracy that is purposefully construed in opposition to nondemocracy.

In these lay theories, HR respect is firmly anchored in Western democracies whereas HR violations only occur in non-Western countries. This justificatory role of democracy has been investigated in studies on the democracy-asvalue hypothesis. Here, hostile acts committed by egalitarian-democratic groups against hierarchical-nondemocratic groups were perceived as less illegitimate compared with those committed in any other victim-perpetrator group configuration (Falomir-Pichastor, Staerklé, Depui- 
set, \& Butera, 2005). Studies specifically concerned with perceived legitimacy of armed conflict confirmed this pattern, showing that democratic military intervention in a nondemocratic country was perceived as the least illegitimate, in particular when supported by a democratic population (Falomir-Pichastor, Staerklé, Pereira, \& Butera, 2012).

In this respect, it is interesting to note that McFarland's (2015) measures of HR commitment, the Human Rights Choices Questionnaire (HRCQ) and the Human Rights Scenarios measure (HRScene), are both based on support for U.S. foreign policy intervention, that is, on outgroup HR concerns. Rather than reflecting general, altruistic HR support, one could then interpret this measure of HR commitment more narrowly as a view of HR as a foreign policy instrument. Indeed, the high correlations between identification with all humanity and HRCQ and HRScene could partially also reflect a tendency by global identifiers to prioritize denunciation of outgroup HR violations rather than to support HR indiscriminately at home and abroad. Finally, it should also be noted that only a few large (mostly Western) countries intervene outside their own territories, and that HR studies concerned with the legitimacy of such foreign interventions represent per se a (majority) view of HR as problems of "others."

\section{In Search of New Models}

The contribution of Bernhard Leidner and Mengyao Li (2015) offers a thoroughly documented theoretical model that allows for integration of some of the elements of our discussion on social identity and commitment to HR. In particular, Leidner and Li (2015) emphasize the importance of group membership in the development of a consciousness of violations and subsequently in the implementation of HR. Even if the theoretical contribution is restricted, in this article, to postconflict situations, the model provides a powerful tool to review the HR studies from a social psychological perspective that can stimulate new research or even new analyses of existing data by following the different paths of the model. In this sense, it constitutes a good answer to McFarland (2015) who calls for a "guiding theory" capable of integrating a collection of disparate studies and empirical results. As discussed earlier, most articles in the issue articulate two perspectives, one referring (at least somewhat) to an intergroup dynamic, including self-definition as a group member, and, more clearly, a second one focusing on individual differences. It seems to us, at the end of this special issue, that there is now solid evidence for the impact of individual measures on the support of HR, and, thanks to this special issue, for the regulation of the restriction of HR by a social identity dynamic that defines everyday thinking. What appears less convincing can be summarized in three points.

First, reflecting a more general problem in attitudinal research, there is a tendency to limit theoretical innovation to the addition of novel individual difference variables rather than attempting to develop basic and meaningful theoretical models. The dual-process theory of ideology and prejudice of Duckitt (2001) could be a stimulating base to do this, as indirectly suggested by McFarland (2015).

Second, following Doise's ideas, the study of HR implies the articulation of different levels of analysis, as partially carried out by Abrams and his colleagues (2015) in this issue. However, such an articulation supposes to define the relevant level of community in which people act to understand the norms intervening in their positioning (Elcheroth, 2006; Elcheroth et al., 2011; Spini \& Doise, 2005). In this regard, HR should be analyzed as normative principles at work at different levels of analysis in asymmetric social interactions. The national level should certainly be considered, given that national boundaries encapsulate a set of normative principles through a common language, a shared historical memory, and a common law. But other levels need to be considered too in order to integrate vertical and horizontal divisions of HR perspectives, not only as targets as in the studies by Abrams and colleagues (2015) and by Hackett and colleagues (2015), but also as subjects. By considering different levels associated with intergroup violence, the Leidner and Li (2015) model could help define relevant categorization levels to study the restriction of HR principles to various groups by other groups and sometimes by their own members. This point is also important to avoid convenient and imprecise characterizations of certain intergroup differences (e.g., "cultural," "affective" differences).

The third point concerns the articulation between theoretical and methodological approaches. By using Bandura's model of moral disengage- 
ment, Malley-Morrison and her colleagues (2015) follow a theoretical approach different from the social identity perspective we have discussed. Of course, this model is relevant in particular to examine how people talk and reason about HR. Furthermore, Malley-Morrison and colleagues (2015) consider the stimulating work by Lakoff and Johnson (1980) on metaphors to link the different mechanisms of moral disengagement to their open-ended technique of questioning. Their findings provide an important contribution regarding the convergence and divergence of HR content as well as the sociocognitive thinking followed by the participants (see also Curtin \& Steward, 2012; Hoppe-Graff \& Kim, 2005). The polysemy of the HR category-much like other broad and abstract concepts such as justice or equality-requires different methodological perspectives and multiple forms of data collection to improve our understanding of the positioning of people toward these concepts. Importantly, however, this approach also necessitates a strong theoretical framework able to support and analyze such data. In this respect, the social representations perspective could offer a stimulating framework to complement the one proposed by Leidner and Li (2015) to systematically explore how people translate the abstract concept of HR into different kinds of specific and concrete rights and how their membership in different communities regulates these translations (Elcheroth et al., 2011; Philogène, 2012).

\section{Conclusion}

To conclude, the articles in this special issue have demonstrated the necessity of questioning the all too easy consensual agreement with abstract and general HR principles by studying the substantial variation toward concrete implementation of these principles. Furthermore, we have emphasized that everyday HR thinking and behavior is often shaped by identity and political concerns that grow out of asymmetric intergroup relations. In this sense, the studies suggest that the way HR are understood and employed by individuals depends to a large extent on the social and political contexts in which they are enacted. In particular, it appears crucial to differentiate the meanings that majorities and minorities associate with HR and to uncover the multiple rhetorical uses that can both challenge and support existing social and political arrangements.

\section{References}

Abrams, D., Houston, D. M., Van de Vyver, J., \& Vasiljevic, M. (2015). Equality hypocrisy, inconsistency, and prejudice: The unequal application of the universal human right to equality. Peace and Conflict: Journal of Peace Psychology, 21, 28-46. http://dx.doi.org/10.1037/pac0000084

Chandler, D. (Ed.). (2002). Rethinking human rights: Critical approaches to international politics. New York, NY: Palgrave-Macmillan. http://dx.doi.org/ 10.1057/9781403914262

Clémence, A. (2001). Social positioning and social representations. In K. Deaux \& G. Philogène (Eds.), Representations of the social (pp. 83-95). Oxford, UK: Blackwell.

Cohrs, J. C., Maes, J., Moschner, B., \& Kielmann, S. (2007). Determinants of human rights attitudes and behavior: A comparison and integration of psychological perspectives. Political Psychology, 28, 441-469. http://dx.doi.org/10.1111/j.1467-9221 .2007.00581.x

Curtin, N., \& Steward, A. J. (2012). Linking personal and social histories with collective identity narratives. In S. Wiley, G. Philogène, \& T. A. Revenson (Eds.), Social categories in everyday experience (pp. 83-102). Washington, DC: American Psychological Association. http://dx.doi.org/10.1037/ 13488-005

Delmas-Marty, M. (1989). Raisonner la raison d'Etat [Reasoning With the Reasons of State]. Paris, France: Presses Universitaires de France.

Doise, W. (2002). Human rights as social representations. London, UK: Routledge.

Duckitt, J. (2001). A dual-process cognitivemotivational theory of ideology and prejudice. $A d$ vances in Experimental Social Psychology, 33, 41113. http://dx.doi.org/10.1016/S0065-2601(01) 80004-6

Elcheroth, G. (2006). Individual-level and community-level effects of war trauma on social representations related to humanitarian law. European Journal of Social Psychology, 36, 907-930. http:// dx.doi.org/10.1002/ejsp.330

Elcheroth, G., Doise, W., \& Reicher, S. (2011). On the Knowledge of politics and the politics of knowledge: How a Social Representations approach helps us rethink the subject of Political Psychology. Political Psychology, 32, 729-758. http://dx.doi.org/10.1111/j.1467-9221.2011 .00834.x

Ellemers, N., Spears, R., \& Doosje, B. (2002). Self and social identity. Annual Review of Psychology, 53, 161-186. http://dx.doi.org/10.1146/annurev .psych.53.100901.135228 
Ethier, K. A., \& Deaux, K. (1994). Negotiating social identity in a changing context: Maintaining identification and responding to theat. Journal of Personality and Social Psychology, 67, 243-251. http://dx.doi.org/10.1037/0022-3514.67.2.243

Falomir-Pichastor, J.-M., Staerklé, C., Depuiset, M.-A., \& Butera, F. (2005). Democracy justifies the means: Political group structure moderates the perceived legitimacy of intergroup aggression. Personality and Social Psychology Bulletin, 31, 1683-1695. http://dx .doi.org/10.1177/0146167205278260

Falomir-Pichastor, J. M., Staerklé, C., Pereira, A., \& Butera, F. (2012). Democracy as justification for waging war: The role of public support. Social Psychological \& Personality Science, 3, 324-332. http://dx.doi.org/10.1177/1948550611420172

Finkel, N. J., \& Moghaddam, F. M. (Eds.). (2005). The psychology of human rights and duties: Empirical contributions and normative commentaries. Washington, DC: American Psychological Association. http://dx.doi.org/10.1037/10872-000

Fiske, S. T., Cuddy, A. J., Glick, P., \& Xu, J. (2002). A model of (often mixed) stereotype content: Competence and warmth respectively follow from perceived status and competition. Journal of Personality and Social Psychology, 82, 878-902. http://dx.doi.org/10.1037/0022-3514.82.6.878

Grabe, S., \& Dutt, A. (2015). Counter narratives, the psychology of liberation, and the evolution of a women's social movement in Nicaragua. Peace and Conflict: Journal of Peace Psychology, 21, 89-105. http://dx.doi.org/10.1037/pac0000080

Hackett, J. D., Omoto, A. M., \& Matthews, M. (2015). Human rights: The role of psychological sense of global community. Peace and Conflict: Journal of Peace Psychology, 21, 47-67. http://dx .doi.org/10.1037/pac0000086

Hoppe-Graff, S., \& Kim, H. O. (2005). Understanding rights and duties in different culture and contexts: Observations from German and Korean adolescents. In N. J. Finkel \& F. M. Moghaddam (Eds.), The psychology of rights and duties: Empirical contributions and normative commentaries (pp. 49-74). Washington, DC: American Psychological Association. http://dx.doi.org/10.1037/ 10872-003

Kull, S., Ramsay, C., Weber, S., Lewis, E., Brouwer, M., Ciolek, M., \& Medoff, A. (2008). World public opinion on torture. Retrieved from WorldPublicOpinion. org at http://www.worldpublicopinion.org/ pipa/pdf/jun08/WPO_Torture_Jun08_packet.pdf

Lakoff, G., \& Johnson, M. (1980). Metaphors we live by. Chicago, IL: University of Chicago Press.

Leidner, B., \& Li, M. (2015). How to (re)build human rights consciousness and behavior in postconflict societies: An integrative literature review and framework for past and future research. Peace and
Conflict: Journal of Peace Psychology, 21, 106132. http://dx.doi.org/10.1037/pac0000082

Lorenzi-Cioldi, F., \& Clémence, A. (2001). Group processes and the construction of social representations. In M. Hogg \& S. Tindale (Eds.), Blackwell handbook in social psychology, Vol. 3: Group processes (pp. 311-333). Oxford, UK: Blackwell. http://dx.doi.org/10.1002/9780470998458.ch13

Malley-Morrison, K., Caputi, R., Gutowski, E., Campbell, T., Estuar, R. E., Akhurst, J., . . . Stevens, M. J. (2015). Engaging moral agency for human rights: Outlooks from the global south. Peace and Conflict: Journal of Peace Psychology, 21, 68-88. http://dx.doi.org/10.1037/pac0000085

McFarland, S. (2015). Culture, individual differences, and support for human rights: A general review. Peace and Conflict: Journal of Peace Psychology, 21, 10-27. http://dx.doi.org/10.1037/ pac0000083

Moghaddam, F. M., \& Vuksanovic, V. (1990). Attitudes and behavior toward human rights across different contexts: The role of right-wing authoritarianism, political ideology, and religiosity. International Journal of Psychology, 25, 455-474. http://dx.doi.org/10.1080/00207599008247877

Moscovici, S. (1961/2008). Psychoanalysis: Its image and its public. Cambridge, UK: Polity Press.

Philogène, G. (2012). Understanding social categories. In S. Wiley, G. Philogène, \& T. A. Revenson (Eds.), Social categories in everyday experience (pp. 31-43). Washington, DC: American Psychological Association. http://dx.doi.org/10.1037/ 13488-002

Plant, E. A., \& Devine, P. G. (1998). Internal and external motivation to respond without prejudice. Journal of Personality and Social Psychology, 75, 811-832. http:// dx.doi.org/10.1037/0022-3514.75.3.811

Reese, G., Berthold, A., \& Steffens, M. C. (2012). We are the world-And they are not: Prototypicality for the world community, legitimacy, and responses to global inequality. Political Psychology, 33, 683-700. http://dx.doi.org/10.1111/j $.1467-9221.2012 .00892 . x$

Spini, D., \& Doise, W. (1998). Organizing principles of involvement in human rights and their social anchoring in value priorities. European Journal of Social Psychology, 28, 603-622. http://dx.doi.org/ 10.1002/(SICI)1099-0992(199807/08)28:4<603:: AID-EJSP884>3.0.CO;2-P

Spini, D., \& Doise, W. (2005). Universal human rights and duties as normative social representations. In N. J. Finkel and F. M. Moghaddam (Eds.), The psychology of human rights and duties: Empirical contributions and normative commentaries (pp. 21-48) Washington, DC: American Psychological Association.

Staerklé, C. (2005). L'idéal démocratique perverti: Représentations antagonistes dans la mise en alté- 
rité du non-Occident [The perverted ideal of democracy: Antagonism in representations of the non-West]. In M. Sanchez-Mazas \& L. Licata (Eds.), L'autre: Regards psychosociaux [The other: Psychosocial views] (pp. 117-148). Grenoble, France: Presses Universitaires de Grenoble.

Staerklé, C. (2009). Policy attitudes, ideological values and social representations. Social and Personality Psychology Compass, 3, 1096-1112. http:// dx.doi.org/10.1111/j.1751-9004.2009.00237.x

Staerklé, C., \& Clémence, A. (2004). Why people are committed to human rights and still tolerate their violation: A contextual analysis of the principleapplication gap. Social Justice Research, 17, 389406. http://dx.doi.org/10.1007/s11211-004-2058-y

Staerklé, C., Clémence, A., \& Doise, W. (1998). Representation of Human Rights across different national contexts: The role of democratic and non-democratic populations and governments.
European Journal of Social Psychology, 28, 207226. http://dx.doi.org/10.1002/(SICI)10990992(199803/04)28:2<207::AID-EJSP865>3.0 .CO;2-5

Stellmacher, J., Sommer, G., \& Brähler, E. (2005). The cognitive representation of human rights: Knowledge, importance, and commitment. Peace and Conflict, 11, 267-292. http://dx.doi.org/ 10.1207/s15327949pac1103_4

Tajfel, H., \& Turner, J. C. (1979). An integrative theory of intergroup conflict. In W. G. Austin \& S. Worchel (Eds.), The social psychology of intergroup relations (pp. 33-47). Monterey, CA: Brooks \& Cole.

Turner, J. C., Hogg, M. A., Oakes, P. J., Reicher, S. D., \& Wetherell, M. S. (1987). Rediscovering the social group: A self-categorization theory. Oxford, UK: Blackwell.

\section{Call for Papers: Experimental and Clinical Psychopharmacology Special Issue for August 2015 on: Sex Differences in Drug Abuse: Etiology and Implications for Prevention and Treatment}

The goal of this special issue is to broadly highlight how males and females differ in their risks for substance abuse, in their responses to treatments, and in their relapse to substance use after a period of abstinence. Relevant approaches include (but are not limited to) laboratory behavioral, social behavior and environmental context, brain development and function, and the role of genetics, hormones and neuropeptides. Both animal and human methods are appropriate for this issue. Collaborative manuscripts that bridge animal and human findings are especially valued.

This special issue is intended to showcase the importance of studying sex differences in drug abuse and how this research might lead to more tailored approaches for prevention and treatment. Laboratories engaged in research in this area may submit review articles or primary research reports to Experimental and Clinical Psychopharmacology to be considered for inclusion in this special issue.

Manuscripts should be submitted as usual through the APA Online Submission Portal (www.apa.org/pubs/journals/pha/), and the cover letter should indicate that the authors wish the manuscript to be considered for publication in the special issue on Sex Differences in Drug Abuse. All submissions will undergo our normal peer review. Manuscripts received no later than March 6, 2015 will be considered for inclusion in the special issue. We strongly encourage individuals to contact us in advance with their ideas and ideally a draft title and abstract.

Questions or inquiries about the special issue can be directed to the Guest Editor of the issue, Brady Reynolds, PhD, at brady.reynolds@uky.edu or the Editor, Suzette Evans, PhD at se18@columbia.edu. 